\title{
BIG FIRE, LITTLE MAN
}

\section{Cate Marvin}

I typed until I thought my hands would fall off. Five days a week, eight hours a day, I typed to the oozing voices of shrinks dictating everything they'd learned about their patients' lives. United Behavioral Systems had three licensed psychologists, one licensed psychiatrist, and a receptionist who kept track of appointments. Then there was me, who they'd hired to type it all down. Because I was always wearing headphones and typing furiously, I never spoke much with any of the shrinks or, for that matter, the receptionist.

After meeting with a patient, the doctor would deliver his account to a tape recorder. I sat in the main office area, my workspace partially obscured by a cubicle partition; if I turned my head, I could see the receptionist's desk and the reception window above it. A passing doctor might drop another cassette on my desk; I would be too intent on typing to notice. The tape player had a foot pedal, like that of a sewing machine or car, which helped regulate the voice's speed. I'd press the pedal deeper, accelerating the voice until it became a litany, typing after it faster and faster. So many troubles were funneled through me, poured into my ears, then out from my fingers. Once I'd typed the patients' lives down, inked their characters on white paper, the receptionist would file them away.

And then there were the people in the waiting room, each one of them no doubt having a bad time of it. Sometimes when the receptionist slid the window open to take down an appointment, I'd turn to look out to catch a glimpse of their faces. The room looked as dull as any waiting room. The patients varied in age and appearance, but they all sat with clipboards on their laps, intently filling out what I knew was probably the Beck Depression Inventory. The sheet had twenty-one questions, if you could call them that. Each question was a group of four statements and the patient was asked to circle the one which best described how he felt about himself. This form was designed to help alert the doctors to the possibility of homicidal or suicidal intent.

I don't feel disappointed in myself.

I am disappointed in myself. 


\section{I am disgusted with myself.}

I hate myself.

I'd been to the Twin Cities only once before I moved there, and that was during the summer, when I'd visited my friend Nick for a weekend. But from what he told me, I knew I'd like the way winter made the streets empty, and I imagined the inhabitants of the city moving through the tunnels they'd built below the buildings downtown. Quiet as moles, pale as cave creatures, I imagined them moving through the warm passageways a hundred feet or so below the ice and snow. And it comforted me to think of living and working among people who held a grave respect for the elements.

It was Nick who suggested I move to Minnesota. He argued that the winters lasted only half the year, that the city was clean and affordable. As I drove into St. Paul, staring out from the car's salt-encrusted windows, the city struck me as frozen and otherworldly. The buildings downtown rose incongruously against the sky's peculiar blue-gray, and I wondered immediately what settlers were thinking when they decided to drop their bags and build a city amid such weather.

Nick could afford a two-bedroom apartment, and he let me take the room he used as an office. Nick's main pastime was buying and selling records; he called his business Fool's Paradise. The closet was filled with packaging materials: bubble wrap, padded envelopes, spools of clear packing tape. He moved an old futon into the corner of the room, where I slept surrounded by towering stacks of records. The only sense I got of the music he played was that it was all very loud - or perhaps it was only that he played it very loud - that the instruments always sounded like they were in agony. Listening to that music made you feel like your life was a terrible mess and that the song's intent was to tell you exactly that.

I am not particularly discouraged about the future.

I feel discouraged about the future.

I feel I have nothing to look forward to.

I feel that the future is hopeless and that things cannot improve.

IDENTIFYING DATA: Angela is a 31-year-old white, married female who has a B.A. in information management and has been employed as a marketing information specialist for the past month.

PRESENTING COMPLAINT: Angela is presenting for problems related to a long-term habit of folding fabric over and rubbing it together. This creates a sound like a cat purring and also has a vibratory and auditory stimulation. Her mother told her she started this habit before kindergarten. She believes she does this when she is anxious. Her goal for therapy is to find out if it can be controlled without creating a backlash in other areas of her life. He main motivation for learning to control this habit is that it bothers other people, primarily 
her current husband. She also admitted that she has developed a habit of curling the pages of a book to create the sound and stimulation, and can also do this with her two fingers.

FAMILY AND SOCIAL HISTORY: Angela did reveal a family history of some mental problems. Her mother did shock treatment after the birth of Angela and before the birth of the next oldest child. The sister is two years younger than Angela. She also indicated her sister had a habit of pulling feathers out from pillows.

Nick didn't have to work because his family owned a major department store; not one you'd hear about on the East Coast, where I'm from, but big for Minnesota. They were rich as hell, the father and the grandfather, and everyone else in their family for that matter. His parents lived in Edina, the wealthiest suburb outside the Twin Cities. Their house was full of antiques and leather couches, and sat edged up right against a lake; they even owned a boat. The summer I visited, Nick took me along for his parents' anniversary party, and they took us all out on the lake. The night was dark and quiet, and Nick's father had paid someone to set off fireworks from the other side of the lake. The lights bloomed into the black sky, one after another, showering color across the water's surface. One cloud of red lights flowered into a shape that faintly resembled a heart. Everyone on board sighed, including me - everyone except Nick, who despised his parents, despite the fact he would have starved without them. At the end of every month, his parents sent him a check written out for an amount I couldn't have earned if I typed twenty-four hours a day, six months straight. Nick spent most of it on records.

I don't feel I am being punished.

I feel I may be punished.

I expect to be punished.

I feel I am being punished.

The city's streets were cold and quiet; cars rolled slowly to their stops in slushy traffic. The city itself was really below the ground, contained in the tunnels through which people passed from building to building. The passageways weren't dim and quiet like I'd imagined; instead, the tunnels were brightly lit, and cluttered with shops at points where they intersected. The people below did not need to dress warmly. The tunnels were so hot that when I walked through them during my lunch break, I felt as though I were being digested. Rather than moving through the tunnels, the crowds moved me, propelling me back to the office, our shared destination.

Some weekends when we went to the Grand Tavern, I tried to tell Nick about how I felt like I was being swallowed up by the place. "Will you quit yakking," he'd plead, “about your damn job?” After we'd ordered more drinks, I'd forget I wasn't supposed to be telling him how tired I was, that my hands 
hurt from typing all day, that I was constantly worried about a lot of people with a lot problems. People I'd never meet, and wouldn't recognize if I did, since I only knew about their lives through the bored voice of Dr. McNairy oozing into the headphones. Or the compassionate voice of Dr. Stanfa, who prescribed medication only when he felt it was absolutely necessary; or the critical voice of Dr. Segura-Hanson who began all of his intakes by making a quick note of his patient's intelligence level ("Moderate to low, in my estimation."). All the people they told me about; the people they were trying to help.

Straddling the chair he'd stationed in front of his turntable, Nick leaned to adjust a few knobs on his stereo. The horn's moan rose to a scream, and I closed the book I'd spent the last hour trying to read. I watched him walk into the kitchen to refill his gin and tonic. He was a big guy and drank a big drink. He cracked the ice from its tray, poured the clear syrup of chilled gin into his glass, then topped it off with an inch of tonic. He pulled a bandanna from his back pocket, mopped his forehead. He carried his drink back into the room, sat in his chair and turned the music down so I could hear him. "Any stories?"

"What," I said flatly, "would you like to hear about."

"Did you bring home any freaky stories?" He raised his eyebrows. "Any ladies who like to rub fabric together because they get off on the vibration? What'd that one lady like - corduroy?"

"I regret telling you about that."

"Someone's had a bad day," Nick said.

"Someone's having a bad life," I snapped.

IDENTIFYING DATA: Brenda is a 24-year-old unmarried, white female who has a B.A. degree in English and has been employed as a typist for the past month. She recently moved to the St. Paul area from her hometown of Baltimore, Maryland.

PRESENTING COMPLAINT: Brenda is here today following a crisis call she made last night from a pay phone outside a bar. She has been living with a close friend this past month since moving to St. Paul and admits she felt too uncomfortable to make the call from his residence. She feels anxious about finances and is trying to save enough money to find her own apartment. She reports feeling lonely and disoriented since the move. She indicated that she and her friend drink on a regular basis, at least every other night. Brenda did not provide details as to why she chose to relocate to Minnesota specifically, though she did make vague references to a man she had been living with in Baltimore. While she admitted experiencing some trauma over the dissolution of their relationship, she claims the main cause of her anxiety and inability to feel safe is due to a fire that occurred in their apartment before she moved out. Most of her belongings were destroyed in this fire. Brenda reports not being able to sleep for more than two to three hours a night. She has a recurring nightmare in 
which she smells smoke and feels very hot, then wakes up afraid she is suffocating.

The house lights flashed on and off inside the Grand Tavern, signaling last call. Nick finished his beer in one long swallow, set his glass down, and leaned across the table. "So," he said, "whatever happened to your little man?"

"We broke up."

"I know," he said. "I know that. I was there for you when it happened, remember? You're looking at the person who spent hours with you on the phone. I' $m$ the one who suggested you get the hell out of there and move here, right?'

"What's your point?" I sat back in the booth, but left my hands on the table, cupped numbly around my drink.

"You're not answering my question," Nick said. "Where did your little man go?"

He waited. "Do you even know?"

"No," I said. "You know what happened. I moved here and got a lousy job. My life has vastly improved thanks to your guidance."

"Don't get bitchy with me," Nick said. "Your problems are small compared to some people's. Everyone gets dumped, cheated on, etc. Everyone's had their heart crushed beneath the tiny sole of a tiny foot of a tiny person like the little men you are always so attracted to."

"Enough abuse for one evening, okay?"

"Blah, blah, blah," Nick said. "Well, I know what happened to your little man, in case you're interested."

I stared back.

Nick leaned closer, his lower lip wet with beer.

"He lives in a teeny, tiny house inside your heart," he said, drawing his words out carefully and pointing his finger at my chest. "And, honey, you've got to burn that little house down or you're never going to get better.' He pressed his finger into my chest bone for a moment, then withdrew it to gesture to the waitress. She walked over and smiled at him, tucking a stray lock of hair behind her ear with her free hand. "One for the road?"

"Gin and tonic," he grinned. "And my friend will have the same."

I don't have thoughts of.killing myself.

I have thoughts of killing myself. but I would not carry them out.

I would like to kill myself.

I would kill myself if I had the chance.

IDENTIFYING DATA: Dennis is a 52-year-old, divorced, white male with an Associate's degree in fire science, and is a St. Paul Fire Captain and has been employed there for the past 24 years. He has three adult children from his first marriage and has been divorced from his second wife for two years.

PRESENTING COMPLAINT: Dennis is here today following a crisis call last 
evening, that he made when he was at home and has a sense of the walls closing in on him. Dennis has been feeling alone and depressed since his divorce two years ago. Dennis indicated his divorce was the result of his wife's drug addiction to marijuana. There was a drug bust at Dennis' house and they both were arrested. Dennis was acquitted, and his wife was convicted. Dennis reports that he is still very much in love with his former wife, but because of her problems he is unable to be close to her. He states that he has no friends and his phone never rings. Dennis also reports that because of the drug arrest and legal process, he is harassed at work by his coworkers, and they poke fun at him. Dennis reports his sleep is disturbed and during the night he has been known to get into his car and start driving. Once he ended up just across the Canadian border. There was another time when he rode his bicycle to Pine City, which is 40 miles away. He also reports some minor shoplifting, which is quite disturbing to him because it is not usual behavior; he indicated it was very minor, such as things of little value from a garage sale. He denies any auditory or visual hallucinations; he does report he has visions of reliving the night of the bust over and over in his head, indicating that it was a very dramatic affair with machine guns; he was made to lie on the kitchen table with a gun pointed at his head.

Nick said I should stay with him until I saved enough to rent a decent apartment.

I once asked to borrow the money, arguing that a loan would be in his best interest since it'd get me out of his hair. He insisted he didn't mind having me around, that I kept the place clean and, for the most part, kept out of his way. Besides, he said, he only used his office during the day, when I was away at work. He offered to move some of his records into the living room to give me more space.

Sometimes during my lunch break I'd look through the classifieds, circle the few apartments that seemed vaguely affordable. A couple of times I almost picked up the phone at work, determined to at least research the possibility of finding my own space. I hesitated: Nick was the only person I knew in town. I could head home with the certainty that he' $d$ be there, waiting, his apartment too alive with music. I tried to imagine what my own place would look like, and could only conjure blanks walls and silence.

I wasn't certain I wanted to stay in Minnesota. I hadn't made friends at the office, which was only natural considering the fact I was always wore headphones and typed with a fury that kept others at bay. And whenever I did manage to talk with one of the doctors, or even the receptionist, they' $\mathrm{d}$ say things like, "You're not from here, are you?" And then not just, "Why did you move to Minnesota?" but "Why did you move?"

I've never liked lying, and I wouldn't know how to explain. Could I have told them I wanted to live closer to Nick, an old college friend, or should I have laid it all on the line and said it was all because of a Little Man, who owned a few very small things, along with a little bag to put these little things in, all of 
which were very light and easy to carry. How he lit a match and crept down the street, never to be seen again.

I would tell them I needed a change in climate.

"Have you experienced one of our winters yet?" the receptionist asked with a sly smile that translated into: "You don't know what the hell you're getting yourself into, and I can't wait to see your face in a few months when it's 20 below and your car won't start, and your nose is frozen, and the air enters your lungs like a knife, and your bones feel like they' re going to crack, and then you'll know what terrible sorts of weather we've had to deal with all our lives."

Nick's parents insisted he come home for the weekend to celebrate his twenty-fifth birthday. Their expansive living room held more valuables than entire generations of my family combined could have racked up. Nick's brothers, sisters, aunts, cousins, and grandparents arrived to dine at the massive table his mother had set with silver and crystal; rich medallions of beef bled on each porcelain plate. The best meat a family could buy in the Twin Cities, his mother told us in a moment of pride. I hadn't had such a good meal in a long time; it felt like a gift, drinking glass after glass of his father's expensive red wine.

Nick's father rose to toast his son's birthday, tears collecting in the corners of his old eyes. His mother stood and raised her glass. "It's wonderful to have the family together like this," she said, looking around the table, taking care to meet everyone's eyes. "It's not often we have Nick with us. We're also happy that you, Brenda," she said, turning to look at me, "could be a part of this special evening ... and we hope someday you'll be a more permanent part of our family."

Everyone gasped with joy and surprise. I clutched my wine glass, and turned to look at Nick; his expression of mute horror matched mine.

"Don't get any ideas," he joked later, when we sat up drinking after the family left and his parents had gone to bed.

"We're already living together," I said.

"My parents think you moved here because we're secret lovers," Nick said, smiling slightly.

"Did you ever tell them why I came here?" I asked.

"No," he said, sipping his glass of Scotch. "It's none of their business."

"It's nice your parents are still together."

"They won't be much longer."

"But they seem so happy," I insisted. "Your father practically cried when your mother gave her toast."

"They put on a good show," Nick sneered.

"Nick," I said. "Do you think you'll ever get married?"

"No." He smiled. "It'd make them too happy."

"But they threw you such a nice dinner-"

"I got what I came for," he said, patting the check folded inside his breast pocket. 
My appetite is no worse than usual.

My appetite is not as good as it used to be.

My appetite is much worse now.

I have no appetite at all anymore.

That night as I lay in the guest bedroom at Nick's parents' house, I tried to sleep and fell instead into thinking about Dennis and the time he drove to the Canadian border, restless with grief over losing his drug fiend wife. I thought about what it' $d$ be like to make that drive myself, and wondered if I' $d$ find him there. I'd park on the side of the highway, pull the parking brake on and leave the car running. I'd get out and walk through the snow, follow the fresh tracks cut by the tires of a car parked just ahead of mine. I' $d$ know him right away: his broad, fireman's chest, his 52-year-old body thick around the middle, and he would know me. He would have seen me through the reception window at United Behavioral Systems when he'd stopped to make another appointment, and he'd say, Hey, I thought you always wore headphones - or he'd joke, I didn't know they ever let you take those headphones off.

Don't worry about fires when you're with me.

You sure have pretty ears. And he'd inch closer, slowly, and then he'd take his glove off and touch my neck with his warm hand. He would close his mouth over the cold stone of my ear and pour his warm breath into my ear canal until it flowed through my whole body. And tears would run quietly down our faces, then seep into the ground, and melt straight through all the snow around us. The earth would be plain beneath us, fertile as spring; we'd thaw the ground until it crumbled beneath us, until we tumbled down into the tunnel of our pleasure. 